\title{
EVALUATION OF THE DEFICIT IRRIGATION REGIMES USING DRIP AND GATED PIPE IRRIGATION SYSTEMS ON YIELD OF MAIZE IN HEAVY EGYPTIAN SOIL
}

\author{
Abdelaziz I. Omara*
}

\section{ABSTRACT}

The aim of this paper was to evaluate the effects of surface drip irrigation (D.I.) and gated pipe (G.P.) furrow irrigation systems at four levels of irrigation $120 \%, 100 \%, 80 \%$ and $60 \%$ of the crop water requirement $\left(E T_{c}\right)$ on maize (Zea mays L., Varity Single Cross No. 10) grain yield and irrigation water use efficiency in heavy soil. The experimental design was a split- block design (strip design) with four replications in a randomized complete block design. Field study was conducted at Itay El-Baroud, ElBeheira Governorate, Egypt.

CROPWAT model was used to evaluate drip and gated pipe irrigation systems and on crop performance under different water irrigation amount. The results showed that there was no significant amount of water losses by deep percolation $(D P)$ in drip irrigation treatments except, in case of crop stress coefficient $(K s)=1.2$, where the DP losses was $52.4 \mathrm{~mm}$ which represent 0.8 of the least value of DP losses in furrow gated pipe irrigation treatment at $K s=0.6$. However, under G.P. furrow irrigation the DP reached 225, 135.1, 84.8 and $65.2 \mathrm{~mm}$ at gross irrigation depth (dg) of $670.3,578.5,486.8$ and $395.1 \mathrm{~mm}$ respectively.

The field results revealed that the highest amount of water applied was $6702.5 \mathrm{~mm}$ at $120 \%$ of $E T_{c}$ with G.P. furrow irrigation, and the lowest amount was at surface drip irrigation (D.I.) $2774.9 \mathrm{~mm}$ at $60 \%$ of $E T_{c}$. Nevertheless, the highest grain yield was 12.89 t/ha resulted from drip irrigation, and the lowest grain yield was 5.17 t/ha from G.P. furrow irrigation. The highest values of water use efficiency were 3.12, 2.83 and $2.75 \mathrm{~kg} / \mathrm{m}^{3}$ which obtained from surface drip irrigation at $80 \%, 100 \%$ and $60 \%$ of $E T_{c}$ respectively.

\footnotetext{
*Dr. of Irrigation System, Agricultural and Biosystems Engineering Department, Faculty of Agriculture، Alexandria University, Egypt.
} 
The lowest values of water use efficiency were $1.31,1.59$ and $1.6 \mathrm{~kg} / \mathrm{m}^{3}$ which obtained at 60\%, 80\% and 120 of ET $T_{c}$ with G.P. furrow irrigation system respectively. However, D.I. showed grain water production (GWP) better than G.P. by $40 \%$ more production with lowest amount of water by $7 \%$.

The statistical analysis of variance revealed highly significant interaction of (irrigation system * irrigation treatment) for all traits studied. The drip irrigation (D.I.) *Ks (1.0) considered the best treatment for most traits, but D.I. * Ks (0.8) is considered the best treatment for GWP in $\mathrm{Kg} / \mathrm{m}^{3}$. In average, drip irrigation consumed $74.7 \%$ of water compared to the furrow gated pipe irrigation system at the same water stress. Thus, achieving higher water use efficiencies. This study showed that, for water saving and achieving high water use efficiency, the present study recommended using surface drip irrigation for maize crop in heavy soils over gated pipe furrow irrigation.

Keywords: Drip irrigation, water stress coefficient, deficit irrigation, gated pipe furrow irrigation, irrigation scheduling, water productivity, Maize. CROPWAT model,

\section{INTRODUCTION}

A griculture water demand is one of the serious pressures on water sector in Egypt, since $85 \%$ of total available water is consumed in agriculture and coupled with poor irrigation management (Oweis and Hachum, 2003). Egypt old land located in the Nile Valley and Delta Regions covers a total area of 2.25 million ha and is characterized by alluvial soils (clay to loamy). The Nile is the main source of water for irrigation (FAO, 2005). Under the current situation in Egypt, the limited water resources obliged the government to put serious plans to overcome the gap between supply and demand efficiently. Up till now, farmers in delta and upper-Egypt use primitive methods of irrigation as well as the old traditional fertilization and weed and pest control practices (Abou Kheira, 2005). Irrigation is typically practiced in short furrows surrounded by small basins. This method is inefficient. The increasing scarcity of water in Egypt is now a well-recognized problem. High rate of population growth and 
water demands for irrigation are projected to rise, bringing increased competition between agriculture and other users, require continuous change of the intensive use of agricultural water policy to save more quantities of water (Oweis and Hachum, 2003).

Adeboye et al. (2015) cited that the deficit irrigation can be used to optimize water productivity. Drip irrigation is reported to help achieve yield gains of up to $100 \%$, water savings of up to $40-80 \%$, and associated fertilizer, pesticide, and labor savings over conventional irrigation systems.

Furrow irrigation using gated pipes technique was suggested by Shehata (2009) in maize cultivation to obtain highest yields and highest growth margin in the heavy-clay soils. These results were observed and gave clear results in the areas that have salinization problems. However, Drip irrigation is recommended in areas with waterlogging problems. While subsurface drip irrigation is better in soils with water shortage conditions. Omara (1997) evaluated the hydraulics of using gated pipe for furrow irrigation system.

Among cereals, maize is the second most consumed for both human and animal in Egypt. Maize is grown for its grain and forage twice annually at least allover Egypt (Shehata, 2009). Maize is cultivated in all agroclimatic zones in Egypt from north to south. The cultivated area of maize in 2013 was 703,921 hectares with average productivity equal 7.72 ton/ha. This cultivated area with maize is irrigated using surface irrigation, as it is the most prevailing irrigation system in Egypt. The application efficiency of surface irrigation in Egypt is $60 \%$, which endure wasteful use of water resources. There is a gap between production and consumption of maize in Egypt estimated by around 45\%. This gap is compensated by importation, which put a burden on the country's budget. Low opportunity exists on increasing maize production through area expansion, which is limited by limited water resource. The other avenue to increase maize productivity is through increasing productivity by unit area, which requires long and intensive breeding programs. Taking into consideration high population growth estimated by $1.84 \%$ annually, it is expected that maize production-consumption gap will widen (Zohry et al., 2016). 
Direct relation between crop evapotranspiration $\left(\mathrm{ET}_{\mathrm{c}}\right)$ and maize yield was reported in many studies (Payero et al., 2006a; Payero et al., 2006b; Payero et al., 2006c; Payero et al., 2006d). significant reduction in maize yields would occur if $\mathrm{ET}_{\mathrm{c}}$ was reduced. Limited irrigation was defined by Trooien et al. (1999) as 70\% of total crop ET. Typically, maize would receive 500-600 $\mathrm{mm}$ of irrigation water when fully irrigated. Maize irrigation management depends mainly on accurate estimate of $\mathrm{ET}_{\mathrm{c}}$ on a daily or seasonal basis (Payero et al., 2008).

Deficit irrigation is defined as an optimization strategy in which irrigation is applied during nondroughted sensitive growth stages of a crop (English, 1990). Deficit irrigation involves irrigating the root zone with less water than the maximum evapotranspiration (Zegbe-Domínguez et al., 2003). Deficit irrigation has been extensively studied on several crops and suggested for semiarid and arid regions (Kirda et al., 2004). Strategies of deficit irrigation shown to be efficient water conserving practices and it should be applied at the large-scale. (Melvin and Payero, 2007)

Maize plants growth development is sensitive to water stress which can be created by deficit irrigation. Such stress can reduce the yield, this negative effect should be estimated and observed (Payero et al., 2006a; Payero et al., 2006b). Water stress in maize has been shown to reduce canopy height (Traore et al., 2000), leaf area index and root growth (NeSmith and Ritchie, 1992; Traore et al., 2000).

Effect of water stress on maize grain and biomass yields was studied by Traore et al. (2000). Significant reduction in grain yield was observed as result of decreasing yield components like the kernel weight, ear size, and number of kernels per ear. That's why Trooien et al. (1999) found full irrigation of maize more profitable than limited irrigation, while water use efficiency (WUE) to be greater for limited irrigated crops.

CROPWAT is an application software for irrigation planning and management. It can be used to calculate the reference evapotranspiration, crop water requirements and crop irrigation requirements; to develop irrigation schedules under various management conditions and water supply schemes; to estimate the rainfed production and drought effects; 
and to evaluate the efficiency irrigation practices. (Marica, 2005; ElShafei et al., 2015).

The objectives of this study were (i) to analyze and compare between surface drip and gated pipes for irrigating maize using deficit irrigation strategies in heavy Egyptian soil (ii) to evaluate the effects of deficit surface drip irrigation and water regime on yield and water productivity of maize compared to surface gated pipes irrigation systems.

\section{MATERIALS AND METHODS}

\subsection{Experimental site}

Field experiments were conducted during the two successive seasons of 2015 and 2016 using recommended agricultural practices for the region at Itay El- Baroud, El-Beheira Governorate, Egypt. (altitude $17 \mathrm{~m}$ above sea level; latitude $30^{\circ} 55^{\prime} 37.25^{\prime \prime} \mathrm{N}$, longitude $\left.30^{\circ} 36^{\prime} 38.56 " \mathrm{E}\right)$, which represented old land as shown in Fig. (1).

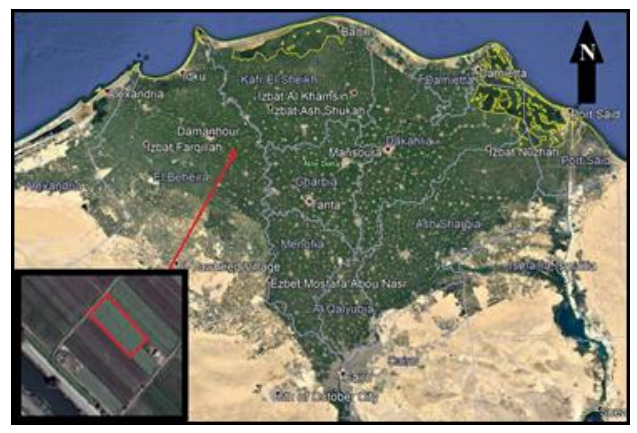

Fig. (1): Experimental site location in old land at Itay El Baroud, Egypt.

\subsection{Soil physical and chemical analysis}

Soil samples were collected from six different randomized locations to represent the whole farm site. They were collected from four different soil depths in range of 0-15 cm, $15-30 \mathrm{~cm}, 30-45 \mathrm{~cm}$ and $45-60 \mathrm{~cm}$. These samples were analyzed for determining selected physical and chemical properties by standard procedures. The bulk density was determined using the undistributed core samples. pressure cooker method was used to determine the soil field capacity (F.C) and permanent wilting point (PWP) at -10 and $-1500 \mathrm{kPa}$ retention, respectively, as described by Richards (1949) then the available water (A.W.) was calculated as the difference 
between the F.C and PWP as shown in Table (1). Basic infiltration rate was determined using a double ring infiltrometer (Bouwer, 1986). The soil texture was determined by hydrometer methods after organic matter (OM) and lime removal according to (Hillel, 1971). The soil salinity (ECe) was determined in the saturated soil paste extract. Also, some soil chemical properties before soil preparation were estimated according to the procedures outlined by Jackson (1962) are shown in Table (2).

Table (1): Some physical properties of the experimental soil before the growing season.

\begin{tabular}{|c|c|c|c|c|c|c|c|c|c|}
\hline \multirow{2}{*}{$\begin{array}{l}\text { Soil } \\
\text { depth } \\
(\mathrm{cm})\end{array}$} & \multicolumn{3}{|c|}{$\begin{array}{c}\text { Particle size } \\
\text { distribution (\%) }\end{array}$} & \multirow{2}{*}{$\begin{array}{l}\text { Soil } \\
\text { texture } \\
\text { class }\end{array}$} & \multirow{2}{*}{$\begin{array}{c}\mathrm{BD} \\
\mathrm{g} \mathrm{cm}^{-3}\end{array}$} & \multirow{2}{*}{$\begin{array}{c}\text { F.C } \\
\% \text { vol. }\end{array}$} & \multirow{2}{*}{$\begin{array}{l}\text { PWP } \\
\% \text { vol. }\end{array}$} & \multirow{2}{*}{$\begin{array}{l}\text { TAW } \\
\% \text { vol. }\end{array}$} & \multirow{2}{*}{$\begin{array}{c}\text { Basic } \\
\text { infiltration rate } \\
\mathrm{f}_{\mathrm{o}}\end{array}$} \\
\hline & Clay & Silt & Sand & & & & & & \\
\hline $0-15$ & 43.3 & 23.3 & 33.4 & $\begin{array}{l}\text { Clay } \\
\text { Loam }\end{array}$ & 1.24 & 41.35 & 17.89 & 23.46 & \multirow{4}{*}{$5 \mathrm{~mm} \mathrm{~h}^{-1}$} \\
\hline $15-30$ & 45.4 & 22.1 & 32.5 & Clay & 1.27 & 37.65 & 17.4 & 20.25 & \\
\hline $30-45$ & 47.6 & 21.8 & 30.6 & Clay & 1.30 & 36.85 & 16.98 & 19.87 & \\
\hline $45-60$ & 48.9 & 22.4 & 28.7 & Clay & 1.35 & 35.40 & 16.62 & 18.78 & \\
\hline Aver. & 46.3 & 22.4 & 31.3 & clay & 1.29 & 37.8 & 17.2 & 20.59 & \\
\hline
\end{tabular}

Table (2): Soil chemical properties for experimental site.

\begin{tabular}{|c|c|c|c|c|c|c|c|c|c|c|c|c|c|c|c|}
\hline \multirow{2}{*}{$\begin{array}{c}\text { Soil } \\
\text { depth } \\
(\mathrm{cm})\end{array}$} & \multirow[t]{2}{*}{$\mathrm{pH}$} & \multirow{2}{*}{ M } & \multirow{2}{*}{$\begin{array}{c}\text { Total } \\
\mathrm{CaCO}_{3} \\
\% \\
\end{array}$} & \multirow{2}{*}{$\begin{array}{c}\mathrm{EC}_{\mathrm{e}} \\
\mathrm{dS} / \mathrm{m}\end{array}$} & \multicolumn{4}{|c|}{ Soluble Cations (meq/l) } & \multicolumn{4}{|c|}{ Soluble Anions (meq/l) } & \multirow{2}{*}{$\begin{array}{l}\text { Total } \\
\mathrm{N} \%\end{array}$} & \multicolumn{2}{|c|}{$\begin{array}{c}\text { Available } \\
\text { (ppm) }\end{array}$} \\
\hline & & & & & $\mathbf{M g}^{++}$ & $\mathbf{C a}^{++}$ & $\mathrm{Na}^{+}$ & $\mathbf{K}^{+}$ & $\mathrm{CO}_{3}{ }^{2-}$ & $\mathrm{HCO}_{3}$ & $\mathrm{SO}_{4}^{2-}$ & $\mathrm{Cl}^{-}$ & & $\mathrm{P}$ & $\mathrm{K}$ \\
\hline & 7.85 & & 16.5 & & & & & & & & & & & 8.5 & 268 \\
\hline $0-60$ & 7.95 & & נI.J. & & 2.63 & 4.82 & 10.41 & & & & & & & 7.7 & 205.0 \\
\hline 30-45 & 8.10 & 1 & 15.15 & 1.97 & 2.7 & 9 & 10 & 0.7 & & & 1 & & 0.42 & 6.8 & 255. \\
\hline 45-60 & 8.20 & 1.35 & 13.89 & 2.10 & 3.10 & 5.03 & 10.5 & & & 4.59 & 13.65 & 4.52 & 0.40 & 6.2 & 250.1 \\
\hline Aver & 8.1 & 1.44 & 15.27 & 1.94 & 2.74 & 4.88 & 10.4 & 0.66 & & 3.55 & 14.11 & & 0.46 & 7.3 & 260. \\
\hline
\end{tabular}

\subsection{Source of irrigation water}

The source of irrigation water of the field experiments is a sub-canal of the Mahmoudiyah canal - the Nile River .The chemical analysis of irrigation water was carried out and presented in Table (3).

Table (3): Irrigation water chemical properties.

\begin{tabular}{|c|c|c|c|c|c|c|c|c|c|c|}
\hline & \multirow{2}{*}{$\begin{array}{c}\mathrm{EC}_{\mathrm{e}} \\
\mathrm{dS} / \mathrm{m}\end{array}$} & \multirow[t]{2}{*}{$\mathrm{pH}$} & \multicolumn{4}{|c|}{ Soluble cations (meq/l) } & \multicolumn{4}{|c|}{ Soluble anions $(\mathrm{meq} / \mathrm{l})$} \\
\hline & & & $\mathrm{Ca}^{2+}$ & $\mathrm{Mg}^{2+}$ & $\mathrm{Na}^{+}$ & $\mathrm{K}^{+}$ & $\mathrm{CO}_{3}{ }^{2-}$ & $\mathrm{HCO}_{3}{ }^{-}$ & $\mathrm{SO}_{4}{ }^{2-}$ & $\mathrm{Cl}^{-}$ \\
\hline Aver. & 1.085 & 7.6 & 3.37 & 1.63 & 2.6 & 0.62 & - & 0.477 & 0.216 & 1.55 \\
\hline
\end{tabular}

\subsection{Experimental design and measurements}

The experimental layouts are shown in Fig. (2) and (3) where the two irrigation systems are separated into two plots. One plot for surface drip 
irrigation (D.I.) as shown in Fig. (2), and the other for furrow gated pipe (G.P.) as shown in Fig. (3).

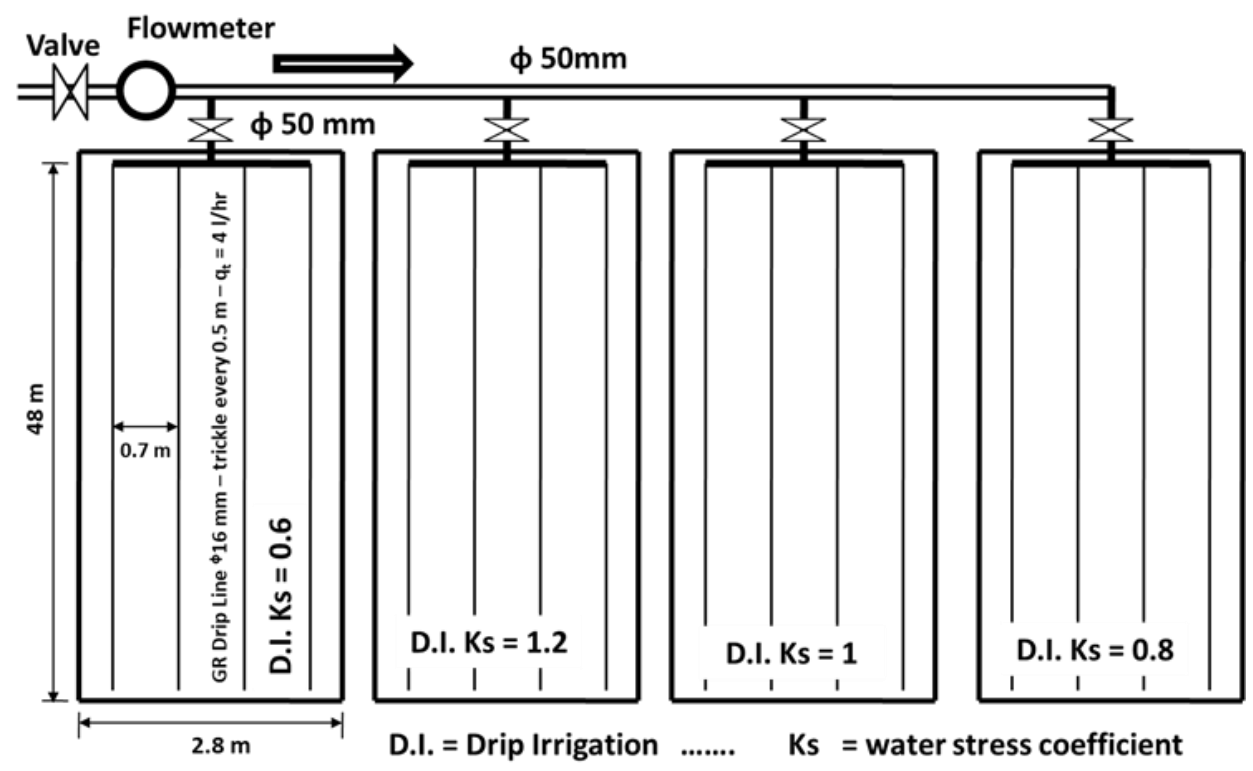

Fig. (2): Layout of surface drip irrigation (D.I.) experimental treatments and replicates.

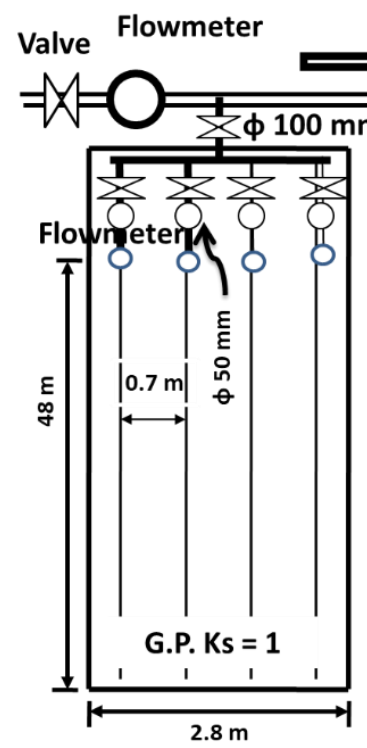

$\Rightarrow \quad \phi 100 \mathrm{~mm}$
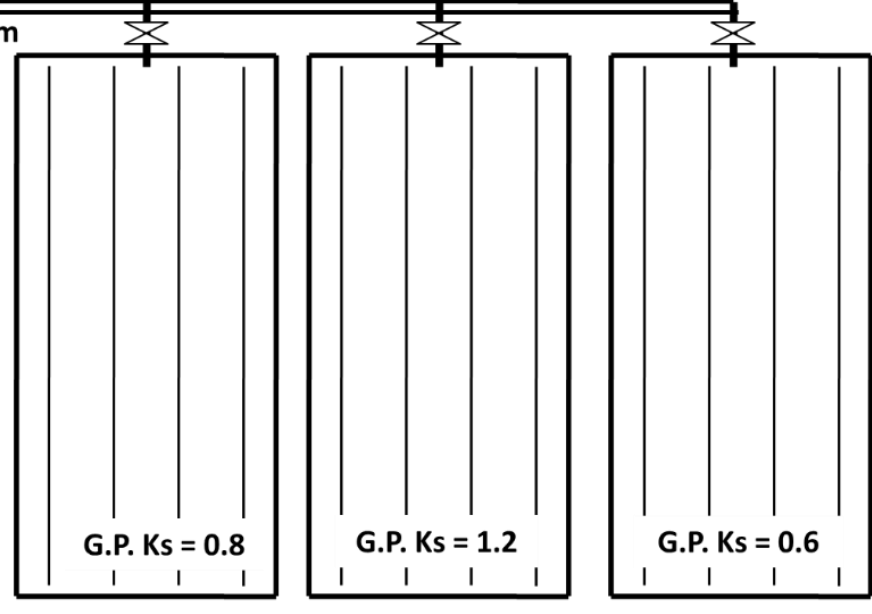

G.P. = Gated Pipe ....... Ks = water stress coefficient

Fig. (3): Layout of furrow gated pipe (G.P.) irrigation experimental treatments and replicates. 
The experimental field was prepared thoroughly by plowing and harrowing then removing the different types of plant residuals. Then the field was leveled, and the furrows were formed with furrows spaced at 0.7 $\mathrm{m}$. The total experimental area was 0.2 ha, divided to three plots, two of them, the surface drip and gated pipe irrigation plots occupied $840 \mathrm{~m}^{2}$ each, (16.8 m width with $50 \mathrm{~m}$ long), between them a buffer zone left $(6.4 \mathrm{~m}$ width with $50 \mathrm{~m}$ long). The surface drip and gated pipe irrigation systems were separated. Each plot was divided into four sub-plots ( $2.8 \mathrm{~m}$ width with $50 \mathrm{~m}$ long), the sub-plot is separated from the other distance by 1.4 meters left without cultivation. Each sub-plot consisted of 4 furrows. The furrow was $48 \mathrm{~m}$ long and $0.7 \mathrm{~m}$ in width with blocked-ends. The field was precision graded to approximately $1 \mathrm{~mm} \mathrm{~m}^{-1}$ slope.

\subsection{Maize cultivates}

The Maize (Zea mays L., Varity Single Cross No. 10) was handed sown at a 4-5 cm depth with 3 seeds per hill. The distance between the hill was 25 $\mathrm{cm}$ along the furrow and the distance between the furrows was $70 \mathrm{~cm}$. The planting date was on $2^{\text {nd }}$ of July, 2015 and on 25 of Jun 2016 on a wellprepared seedbed, the maize grain yields and yield components were determined by hand harvesting individual after 110 days from planting. Data was collected from every single row/furrow in the sub-plots.

\subsection{Fertilization}

A basal dose of $250 \mathrm{~kg} \mathrm{~N}+100 \mathrm{P}_{2} \mathrm{O}_{5}$ per hectare was used. Full dose of phosphorous in the form of ammonium phosphate was applied at the time of planting. For gated pipe (G.P.) furrow irrigation treatments half required nitrogen dose was applied manually in at side dressing after thinning. Thinning was practiced at 4-6 leaf stage. Half of the remaining required nitrogen dose was divided evenly on the second and third irrigation events when plant age was 32, 42 and 31 days from planting respectively. But for surface drip irrigation (D.I.) the fertilizer dose was added by fertigation (in the suction sump of the pump), the required nitrogen dose was divided evenly on eight irrigation events when plant age was 12, 16, 20, 24, 30, 33, 36 and 39 days from planting respectively. All other agronomic practices were kept normal and uniform for all the treatments under study.

\subsection{Field irrigation systems}

A Maize field experiment with surface D.I. systems in comparison to G.P. furrow irrigation systems were conducted. The irrigation systems were 
used equipped with a control head consisting of electrical centrifugal pump, none return valve, pressure regulator, control valve, pressure gauges, media filter, disc filter and flow meter. During the growing season, each row of the first sub - plots of the maize crop was irrigated using a single surface lateral line D.I. Drip tubing (GR type, $16 \mathrm{~mm}$ diameter) with $0.50 \mathrm{~m}$ emitter spacing built in, each delivering $4 \mathrm{~L} \mathrm{~h}^{-1}$ at 1 bar pressure, each drip irrigation sub-plot system had one valve, one pressure gauge and one flowmeter to control the operating pressure and measure the water irrigation volume Fig. (2), While, each four furrows of the second sub - plots of the maize crop were irrigated by four singles G.P. Each one had a valve (50 mm diameter) delivering $90 \mathrm{~L} \mathrm{~min}^{-1}$ at 0.5 bar pressure, one pressure gauge and one flowmeter to control the operating pressure and measure the water irrigation volume Fig. (3).

\subsection{Crop water requirement and irrigation management}

The net daily crop water requirements were calculated using Eq. (1) according to Doorenbos (1975) as follows:

$$
\mathbf{d n}=\mathbf{E T}_{\mathbf{c}}=\mathbf{E T}_{\mathbf{o}} * \mathbf{K c} * \mathbf{K s}
$$

Where: $\mathrm{dn}=$ net irrigation water requirement $(\mathrm{mm})$

$\mathrm{ET}_{\mathrm{c}}=$ crop water requirement $(\mathrm{mm})$,

$\mathrm{ET}_{\mathrm{o}}=$ reference crop evapotranspiration $(\mathrm{mm})$,

$\mathrm{Kc}=$ crop coefficient that varies by crop development stage, and

$\mathrm{Ks}=$ water stress coefficient.

The maize (Kc) was $0.4,0.8,1.1$ and 0.8 for initial, development, midseason and late, respectively (Allen et al., 1998), where stage days were 20, 35, 35 and 10 for initial, development, mid-season and late, respectively, water stress coefficient (Ks) for each irrigation treatment level in the experiment. The crop water requirement $\mathrm{ET}_{\mathrm{c}}$ for seasonal growing months (Jun to October) was determined (6.08, 5.69, 5.33, 4.48, 3.64 $\mathrm{mm} /$ day) using the FAO Penman-Monteith approach (Allen et al., 1998). For purposes of creating irrigation schedules historical weather data of 15 years (2000-2015) was used from the Egyptian Meteorological Data of Tanta $\left(10 \mathrm{~m}\right.$ above sea level, located at $30.80^{\circ} \mathrm{N}$ and $\left.31.00^{\circ} \mathrm{E}\right)$.

The coefficient of each irrigation treatment Ks $(1.2)=120 \%$ of $\mathrm{ET}_{\mathrm{c}}$ an excessive amount of water, Ks $(1)=100 \%$ of $\mathrm{ET}_{\mathrm{c}}$ no stress, $\mathrm{Ks}(0.8)=80 \%$ 
of $\mathrm{ET}_{\mathrm{c}}$ and $\mathrm{Ks}(0.6)=60 \%$ of $\mathrm{ET}_{\mathrm{c}}$. Water was applied by D.I. on the same day to all treatments also water was applied by G.P. furrow irrigation treatments in the same time according to the irrigation schedule.

The gross daily crop water requirements (gross irrigation depth) were calculated by using the following equation (Allen et al., 1998):

$$
\mathbf{d g}=\frac{\mathbf{d n}}{\mathbf{E}_{\mathbf{a}}(\mathbf{1}-\mathbf{L F})}
$$

where: $\mathrm{dg}=$ gross irrigation depth ( $\mathrm{mm})$,

$\mathrm{E}_{\mathrm{a}}=$ water application efficiency, and

LF = leaching coefficient, was calculated according to Ayers and Westcot (1985) as follows:

$$
\mathbf{L F}=\frac{\mathbf{E C}_{\mathrm{i}}}{\mathbf{E C}_{\mathrm{e}}-\mathbf{E C}_{\mathrm{i}}}
$$

where: $\mathrm{EC}_{\mathrm{i}}$ and $\mathrm{EC}_{\mathrm{e}}$ : are the electrical conductivity of irrigation water and the saturated soil extract in $\mathrm{dS} / \mathrm{m}$.

To simulate the irrigation practice for the Itay El- Baroud region, the irrigation interval time in average for drip irrigation (D.I.) treatments was selected to be 3 days, while for gated pipe (G.P.) irrigation treatments, it was 9 days. For each irrigation time, the amount of the applied irrigation water; $\mathrm{W}_{\mathrm{m}}$ in $\mathrm{m}^{3}$ /period was calculated according to the following equation (Cuenca, 1989):

$$
\mathbf{W}_{\mathbf{m}}=\frac{\sum_{1}^{\mathbf{n}} \mathbf{A} * \mathbf{E T}_{\mathbf{o}} * \mathbf{K}_{\mathbf{c}} * \mathbf{K}_{\mathbf{s}}}{\mathbf{E}_{\mathbf{a}}(\mathbf{1}-\mathbf{L F}) * 1000}
$$

where: $\mathrm{A}=$ irrigated area in $\mathrm{m}^{2}$

$$
\mathrm{n}=\text { irrigation period in days }
$$

The water application efficiency of the D.I. system $\left(E_{a}\right)$ was calculated according to Savva and Frenken (2002) as follows:

$$
\mathbf{E}_{\mathbf{a}}=\mathbf{K}_{\mathbf{u}} * \mathbf{E} \mathbf{U}
$$

where: $K_{u}=$ water storage efficiency of soil

$\mathrm{EU}=$ percentage of emission uniformity, 
To determine the EU, four emitter laterals (hose) were located along an operating manifold. Discharges were collected from four emitters on each hose.

$$
\mathbf{E U}=\frac{\boldsymbol{q}_{l q}}{\boldsymbol{q}_{\text {ave }}}
$$

where: $\mathrm{q}_{\mathrm{ave}}=$ total average discharge rate,

$\mathrm{q}_{\mathrm{lq}}=$ average discharge rate of the lowest quarter.

These preceding was repeated at three times (before planting, after 70 days after planting and after harvesting). The EU for present experiment was 0.95 ; however, the $\mathrm{K}_{\mathrm{u}}$ was assumed 0.95 according to Savva and Frenken (2002). Therefore, for D.I., the $\mathrm{E}_{\mathrm{a}}$ was calculated and equal to 0.90 .

But, water application efficiency of the G.P. furrow irrigation system $\left(E_{a}\right)$ was calculated according to the following equation (Doorenbos and Pruitt, 1977):

$$
\mathbf{E}_{\mathbf{a}}=\frac{\mathbf{w C U}}{\mathbf{w}_{\mathrm{m}}}
$$

where: $W C U$ is seasonal water consumptive use. $W C U$ was calculated from the sum of the water consumptive use through the interval irrigation time in $\mathrm{mm}\left(W C U_{m}\right)$ for all irrigation times. $W C U_{m}$ was calculated according to Israelson and Hanson (1962), where soil samples were taken from different soil depths before and after $24 \mathrm{hr}$ of each irrigation time to determine, $W C U_{m}$ as:

$$
\mathbf{W C U}_{\mathrm{m}}=\sum_{\mathrm{i}=1}^{\mathrm{ns}} \frac{\mathbf{M}_{\mathrm{ai}}-\rightarrow \mathbf{M}_{\mathrm{bi}}}{100} \times \gamma_{\mathrm{si}} \times \mathbf{z}_{\mathrm{i}}
$$

where: $\mathrm{m}=$ the irrigation $\mathrm{Nr}$., $\mathrm{i}=$ the soil layer Nr., $\mathrm{ns}=$ the soil layer numbers, $\mathrm{M}_{\mathrm{ai}}$ and $\mathrm{M}_{\mathrm{bi}}=$ represent the soil moisture content by weight (\%) after irrigation by $24 \mathrm{hr}$ and before the next irrigation immediately for layer $\mathrm{i}, \gamma_{\mathrm{si}}=$ the specific bulk density of soil layer, and $\mathrm{z}_{\mathrm{i}}=$ thickness of the soil layer. The three layers $(0-20,20-40$ and $40-60 \mathrm{~cm})$ were taken to represent the effective root zone. From the experimental results, the $E_{a}$ was calculated and equal to 0.80 .

\subsection{Irrigation treatments}

For both irrigation systems, D.I. and G.P. furrow irrigation, required water irrigation depth was applied at four levels of irrigation $(120 \%, 100 \%, 80 \%$, and $60 \%$ ) of the crop water requirement $\left(\mathrm{ET}_{\mathrm{c}}\right)$ and the irrigation treatments 
were replicated four times in each treatment Fig. (1) and (2). Water was applied in different days in D.I. but in case of G.P. in the same day according to the irrigation schedule. Irrigation season of maize was ended 20 days before harvest.

\subsection{CROPWAT model}

The CROPWAT version 8.0 model (Swennenhuis, 2006) was used for calculation of crop water requirements and the development of irrigation schedules for different water management strategies. The input data of the CROPWAT model requires the following climatic, crop and soil data:

- The daily reference crop evapotranspiration $\left(\mathrm{ET}_{\mathrm{o}}\right)$ and daily rainfall data were used from the Egyptian Meteorological Data of Tanta.

- A cropping pattern: consisting of the crop type, planting date, crop coefficient data files including $\mathrm{K}_{\mathrm{c}}$ values and depletion fraction $(p)(0.65$ for initial and mid-season stages, and 0.57 for late season stage) were calculated according to Allen et al. (1998) using the following equation:

$$
\mathrm{p}=p_{\mathrm{ET} 5}+0.04\left(5-\mathrm{ET}_{\mathrm{c}}\right) \ldots \ldots(9)
$$

where: $\mathrm{p}=$ cropping pattern (average fraction of Total Available Soil Water)

$p_{E T 5}=$ soil water depletion fraction for no stress (for maize 0.55 )

- Soil type: total available soil moisture, maximum rain infiltration rate, maximum rooting depth, and initial soil moisture depletion were provided from measured data.

- Scheduling criteria: after the finishing of both seasons of 2015 and 2016 the options of user defined application depth (calculated from Eq. 2) and irrigate at user defined irrigation intervals by days for D.I. and G.P. furrow irrigation were used to develop the irrigation schedule for all treatments were applied. These scheduling criteria for the four irrigation treatments for each season with their climatic data were entered to CROPWAT model and the results of deep percolation (DP), efficiency of the irrigation schedule (EIS), deficiency of the irrigation schedule (DIS) and yield reduction $\left(Y_{R}\right)$ were collected and analyzed.

The efficiency irrigation schedule (EIS) evaluates how advantageously the net irrigation (I) contributions are used by the crop over the growing period. The EIS is expressed as a percentage and computed as the ratio between 
the irrigation water effectively used by the crop, meaning the difference between net irrigation (I) and irrigation losses, and net irrigation (Swennenhuis, 2006). Irrigation water reaching the root zone, that is net irrigation, is not always advantageously used by the crop. Therefore, the EIS could be calculated from the following equation.

$$
\mathrm{EIS}=\frac{\sum\left(\mathrm{I}_{\mathrm{i}}-\mathrm{DP}_{\mathrm{i}}\right)}{\sum \mathrm{I}_{\mathrm{i}}} \times 100
$$

The deficiency irrigation schedule (DIS) is expressed as a percentage and computed as the ratio between the deficit of irrigation water, meaning the difference between the reference water use by crop (seasonal ETc) and actual water use by crop (seasonal $\mathrm{ET}_{\mathrm{c} \text { adj }}$ ), and the reference water use by crop (Swennenhuis, 2006). Thus, the DIS was calculated from:

$$
\begin{aligned}
& \text { Seasonal } \mathrm{ET}_{\mathrm{c}}=\sum\left(\mathrm{ET}_{\mathrm{o}} \cdot \mathrm{K}_{\mathrm{c}}\right) \\
& \text { Seasonal } \mathrm{ET}_{\mathrm{c} \text { adj }}=\sum\left(\mathrm{ET}_{\mathrm{o}} \cdot \mathrm{K}_{\mathrm{c}} \cdot \text { daily } \mathrm{K}_{\mathrm{s}, \mathrm{i}}\right) \ldots \ldots
\end{aligned}
$$

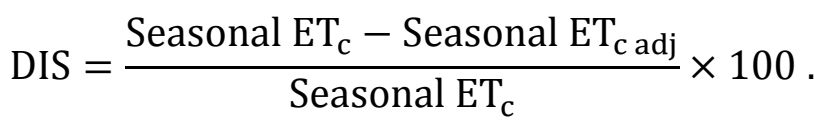

Yield reduction due to soil moisture stress is expressed as a percentage of the maximum production achievable in the area under optimal conditions. It can be computed with reference to a single stage of crop cycle or to the whole growing season. Yield reduction is expressed by applying the following equation:

$$
\mathrm{Y}_{\mathrm{R}}=\left(1-\frac{\mathrm{GY}_{\mathrm{a}}}{\mathrm{GY}_{\max }}\right)=\mathrm{K}_{\mathrm{y}}\left(1-\frac{\mathrm{ET}_{\mathrm{cadj}}}{\mathrm{ET}_{\mathrm{c}}}\right)
$$

where: $G Y_{\mathrm{a}}$ is grain yield achievable under actual conditions, $G Y_{\max }$ is maximum crop yield achievable in case of full satisfaction of crop water needs, and $\mathrm{K}_{\mathrm{y}}$ is yield response factor, which selected to be $0.2,0.6,0.5$, 0.4 and 1.0 for initial-, development-, mid-season-, late season- stages and total growing period, respectively (Doorenbos and Kassam, 1979).

\subsection{Maize yield and yield components}

At harvest, samples of plants were cut randomly and topped to determine the following data; the number of plants in each furrow, weight of ear, plant 
length, plant circumference, thousand-kernel weight, grain yield $(G Y)$ and biological yield.

\subsection{Yield productivity}

The crop water productivity, as reviewed by Kijne et al. (2003), is defined as the ratio of grain yield $(\mathrm{GY})$ to volume of applied water $(\mathrm{W})$ as follows:

$$
\mathbf{G W P}=\frac{\mathbf{G Y}}{\mathbf{W}}
$$

Generally, the relationship between GY and W is called grain water production function (GWPF). The GWPF becomes curvilinear as some of the excess applied water goes to drainage or loss. It reflects the benefit of applied water in production of grain yield or biological yield. The quadratic polynomial function of Helweg (1991) was expressed as follows:

$$
\mathbf{G Y}=\mathbf{b}_{0}+\mathbf{b}_{1} \mathbf{W}+\mathbf{b}_{2} \mathbf{W}^{2}
$$

where, $G Y$ is grain yield $\left(\mathrm{Mg} \mathrm{ha}^{-1}\right), W$ is applied irrigation water $\left(\mathrm{m}^{3} \mathrm{ha}^{-1}\right)$, and $b_{0}, b_{1}$, and $b_{2}$ are fitting coefficients.

When yield approaches its maximum value, the slope of the water productivity function against water applied goes to zero; therefore, the maximum applied water $\left(W_{\max }\right)$ was calculated by differentiating the $G Y$ (Eq. 18) and equalized by zero. Then the maximum predicted yield ( $\left.G Y_{\max }\right)$ was calculated by substituting the $W_{\max }$ in last equation (Ismail, 1993a; Ismail, 1993b; Aly and Benaabidate, 2010).

$$
\begin{gathered}
\frac{\mathbf{d G Y}}{\mathbf{d W}}=\mathbf{b}_{1}+\mathbf{2} \mathbf{b}_{2} \mathbf{W}=\mathbf{0} \\
\mathbf{W}_{\max }=\frac{-\mathbf{b}_{1}}{2 \mathbf{b}_{2}} \quad \ldots \ldots \ldots \ldots \ldots \ldots \\
\mathbf{G Y}_{\max }=\mathbf{b}_{0}+\mathbf{b}_{1} \mathbf{W}_{\text {max }}+\mathbf{b}_{2} \mathbf{W}_{\text {mas }}^{2}
\end{gathered}
$$

\subsection{Crop parameters}

Final yield was determined at the end of the season after the crop was harvested. An electronic balance ( $0.001 \mathrm{~g}$ sensitivity) was used to weigh the maize grain yield from various treatments. Water use efficiency for each treatment under each irrigation system was determined by dividing the harvested grain yield by its seasonal water use. 


$$
\text { CWUE }=\frac{\text { Ya }}{\text { CWU }}
$$

where: CWUE $=$ crop water use efficiency $\left(\mathrm{kg} / \mathrm{m}^{3}\right)$,

$$
\mathrm{Y}_{\mathrm{a}}=\text { actual yield }\left(\mathrm{kg} \mathrm{ha}^{-1}\right) \text {, and }
$$

$\mathrm{CWU}=$ crop water use $\left(\mathrm{m}^{3} / \mathrm{ha}\right)$.

\section{Yield water relation}

The crop yield response data from deficit irrigation were fitted to the following linear equation Stewart et al. (1977).

$$
\mathbf{1}-\frac{\mathbf{Y}_{\mathbf{a}}}{\mathbf{Y}_{\mathbf{m}}}=\mathbf{K}_{\mathbf{y}}\left[\mathbf{1}-\frac{\mathbf{E T}_{\mathbf{a}}}{\mathbf{E T}_{\mathbf{m}}}\right] \ldots \ldots . . .(21)
$$

Where: $Y_{m}=$ maximum yield $\left(\mathrm{t} \mathrm{ha}^{-1}\right)$ from $100 \%$ water requirement,

$\mathrm{Y}_{\mathrm{a}}=$ actual yield $\left(\mathrm{t} \mathrm{ha}^{-1}\right)$ from different level of water requirement, $\mathrm{ET}_{\mathrm{m}}$ and $\mathrm{ET}_{\mathrm{a}}=$ maximum and actual evapotranspiration $(\mathrm{mm})$, and $\mathrm{K}_{\mathrm{y}}=$ yield response factor indicates the response of maize grain production to deficit irrigation.

\subsection{Statistical procedures}

The experimental design was a split- block design (strip design) with four replications in a randomized complete block design. The main plots were occupied by two types of irrigation system. The sub-plots were allocated to four irrigation treatments. F-test, and analysis of variance of treatments difference was performed according to Steel et al. (1980). Statistical analysis was done by, ANOVA, F-test, and L.S.D procedures available within the SAS software package (version 9.13 2008).

\section{RESULTS AND DISCUSSION}

\subsection{Irrigation water amount}

Water applied for maize throughout the growing season by the two systems of irrigation, D.I. and G.P. furrow irrigation was calculated (Table 4) and shown (Fig. 1). The two irrigation systems show a similar trend at the four tested levels of water application. The shortage in the quantities of applied water from $120 \%$ of $\mathrm{ET}_{\mathrm{c}}$ to $100 \%, 80 \%$ and $60 \%$ during the growing season as distributed equally from the second irrigation event until the last irrigation event under D.I. or G.P. and the maximum amount applied irrigation water was achieved at mid-season growing stages in all irrigation 
treatment in D.I. and G.P. but the minimum value of applied water was achieved at Late season growing stages, 20 days before harvest. The highest value of gross water irrigation depth was achieved with the G.P. furrow irrigation technique $\left(670.25 \mathrm{~mm}\right.$ at $120 \%$ of $\left.\mathrm{ET}_{\mathrm{c}}\right)$, and the lowest value was applied with the surface D.I. system ( $277.49 \mathrm{~mm}$ at $60 \%$ of $\mathrm{ET}_{\mathrm{c}}$ ). Therefore, the surface D.I. system is recommended when inadequate water is accessible because of its superior water application efficiency over G.P. furrow irrigation. The application efficiencies were $80 \%$ for furrow irrigation using gated pipes and $95 \%$ for surface D.I.

Table (4): Gross water irrigation depth for D.I. and G.P. irrigation systems over the growing seasons of maize.

\begin{tabular}{|c|c|c|c|c|c|c|c|c|c|c|c|}
\hline \multirow{3}{*}{$\begin{array}{c}\text { Days } \\
\text { from } \\
\text { planting }\end{array}$} & \multirow{3}{*}{$\begin{array}{l}\text { Growing } \\
\text { stage }\end{array}$} & \multirow{3}{*}{ Kc } & \multirow{3}{*}{$\begin{array}{l}\mathbf{E T}_{0} \\
\mathrm{~mm} / \\
\text { day }\end{array}$} & \multicolumn{8}{|c|}{ Gross Irrigation Depth dg $(\mathrm{mm})$} \\
\hline & & & & \multicolumn{4}{|c|}{ Drip irrigation } & \multicolumn{4}{|c|}{ Gated Pipe Irrigation } \\
\hline & & & & $\begin{array}{c}\mathrm{Ks}= \\
1.2\end{array}$ & $\begin{array}{c}\mathrm{Ks}= \\
1\end{array}$ & $\begin{array}{c}\mathrm{Ks}= \\
0.8\end{array}$ & $\begin{array}{c}\text { Ks }= \\
0.6\end{array}$ & $\begin{array}{c}\mathrm{Ks}= \\
1.2\end{array}$ & $\begin{array}{c}\mathrm{Ks}= \\
1.0\end{array}$ & \begin{tabular}{|c|} 
Ks $=$ \\
0.8
\end{tabular} & $\begin{array}{c}\mathrm{Ks}= \\
0.6\end{array}$ \\
\hline $1-20$ & Initial & 0.4 & 5.69 & 67.4 & 61.1 & 54.9 & 48.7 & 130.2 & 128.5 & 126.8 & 125.1 \\
\hline $21-55$ & Development & 0.8 & 5.33 & 189.6 & 158 & 126.4 & 94.8 & 228.2 & 190.2 & 152.1 & 114.1 \\
\hline $56-90$ & Mid-season & 1.1 & 4.48 & 234.9 & 195.7 & 156.6 & 117.4 & 267.1 & 222.6 & 178.1 & 133.6 \\
\hline 91-100 & Late & 0.8 & 3.64 & 33.1 & 27.6 & 22.1 & 16.6 & 44.7 & 37.2 & 29.8 & 22.3 \\
\hline \multicolumn{3}{|c|}{ Total Irrigation depth (mm) } & & 525 & 442.4 & 360 & 277.5 & 670.2 & $\mathbf{5 7 8 . 5}$ & 486.8 & 395.1 \\
\hline
\end{tabular}

$\mathrm{Kc}$ is the crop coefficient --- Ks is the water stress coefficient

The water application depths at average timing intervals of 3 days for drip irrigation treatments and 9 days for furrow gated pipe irrigation treatments for different water stress coefficients (Ks $=0.6,0.8,1.0$ and 1.2), which were calculated using Eq. 4 and applied at field for both seasons 2015 and 2016 are presented in Fig. (4). However, in case of G.P. surface furrow irrigation, the first irrigation depth was $120 \mathrm{~mm}$ which is over calculated by Eq. 2 due to the need to aggregate the soil particles and reform the soil surface as well as to allow the advance of water stream to reach the end of the furrows. But in surface drip irrigation, the first irrigation depth was 30 $\mathrm{mm}$ which is over calculated by Eq. 2 to enhance seed germination.

\subsection{Irrigation scheduling using CROPWAT program.}

The gross irrigation application depths (dg) at timing intervals for the all irrigation treatments shown in Fig. (4) above were entered to CROPWAT model as scheduling criteria with daily calculated $\mathrm{ET}_{\mathrm{o}}$ for the Egyptian Meteorological Data of Tanta ( $10 \mathrm{~m}$ above sea level, located at $30.80^{\circ} \mathrm{N}$ and $\left.31.00^{\circ} \mathrm{E}\right)$. The output of CROPWAT model provided daily root zone 
depletion (daily $\mathrm{D}_{\mathrm{r}, \mathrm{i}}$ ), deep percolation (DP), the daily water stress coefficient $\mathrm{K}_{\mathrm{s}, \mathrm{i}}$, crop actual water use ( $\mathrm{ET}_{\mathrm{c} \text { adj }}$ ), efficiency of the irrigation schedule (EIS), deficiency of the irrigation schedule (DIS). Table (5) shows, the results of crop water requirement.

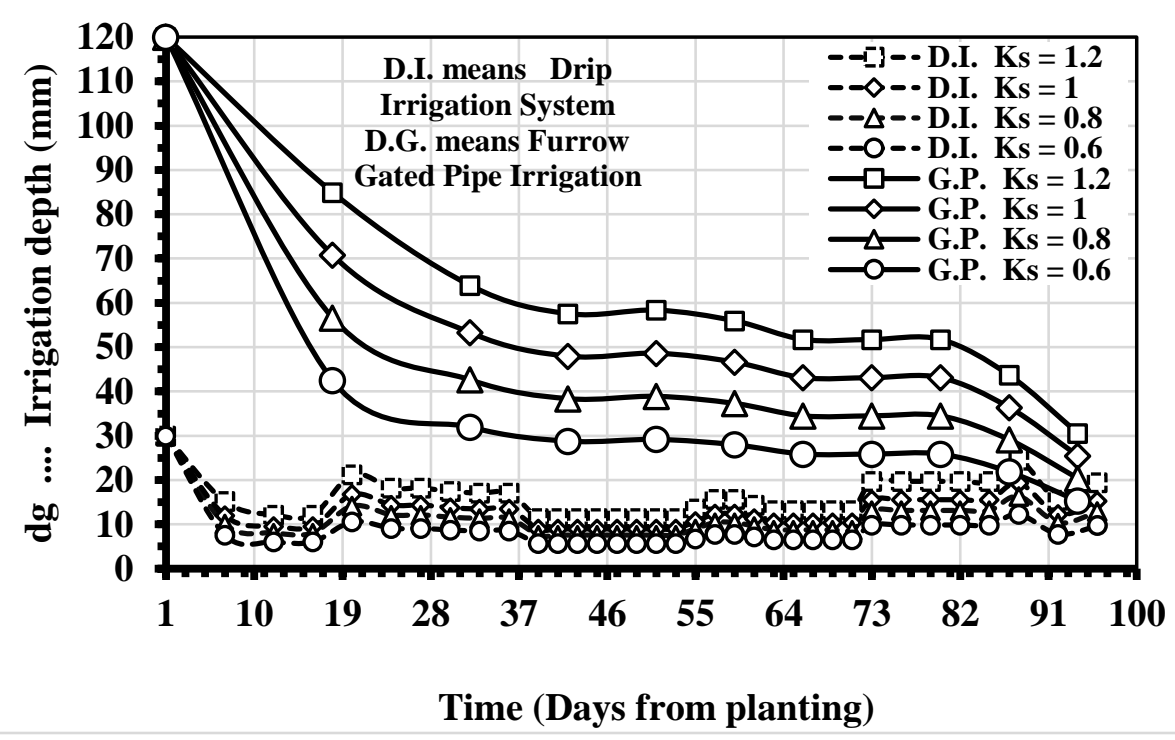

Fig. (4): Gross irrigation application depth along growing season under D.I. and G.P. furrow irrigation systems.

Table (5): Total reference and actual water use by crop, irrigation losses, efficiency of irrigation schedule for different irrigation treatments.

\begin{tabular}{|c|c|c|c|c|c|c|c|}
\hline \multirow[t]{2}{*}{$\begin{array}{c}\text { Irrigation } \\
\text { Treatments }\end{array}$} & $\begin{array}{c}\text { Gross } \\
\text { Irrigation } \\
\text { depth } \\
\text { dg }(\mathbf{m m})\end{array}$ & $\begin{array}{l}\text { Total } \\
\text { Rain } \\
(\mathbf{m m})\end{array}$ & $\begin{array}{c}\text { Crop } \\
\text { Reference } \\
\text { water use } \\
\text { ET }_{\mathbf{c}}(\mathbf{m m}) \\
\end{array}$ & $\begin{array}{c}\text { Deep } \\
\text { percolation } \\
\text { loss DP }(\mathrm{mm})\end{array}$ & $\begin{array}{l}\text { Crop actual } \\
\text { water use } \\
\text { ET }_{\text {c adj }}(\mathbf{m m})\end{array}$ & $\begin{array}{c}\text { Moisture } \\
\text { deficit at } \\
\text { harvest } \\
(\mathrm{mm})\end{array}$ & $\begin{array}{l}\text { EIS } \\
(\%)\end{array}$ \\
\hline & \multicolumn{7}{|c|}{ Drip Irrigation System (D.I.) } \\
\hline$K_{s}=0.6$ & 277.5 & $\mathbf{0}$ & 419.2 & $\mathbf{0}$ & 257.1 & 55.5 & 100 \\
\hline$K_{s}=0.8$ & 360 & $\mathbf{0}$ & 419.2 & $\mathbf{0}$ & 335.3 & 47.7 & 100 \\
\hline$K_{\mathrm{s}}=\mathbf{1 . 0}$ & 442.5 & $\mathbf{0}$ & 419.2 & $\mathbf{0}$ & 403 & 31.4 & 100 \\
\hline \multirow[t]{2}{*}{$K_{\mathrm{s}}=1.2$} & 525 & $\mathbf{0}$ & 419.2 & 52.4 & 413.6 & 8.4 & 90.1 \\
\hline & \multicolumn{7}{|c|}{ Gated Pipe Irrigation System (G.P.) } \\
\hline$K_{s}=0.6$ & 395.1 & $\mathbf{0}$ & 419.2 & 65.2 & 316.6 & 55.3 & 83.5 \\
\hline$K_{s}=0.8$ & 486.8 & $\mathbf{0}$ & 419.2 & 84.8 & 374.9 & 41.1 & 82.6 \\
\hline$K_{s}=1.0$ & 578.5 & $\mathbf{0}$ & 419.2 & 135.1 & 390.9 & 17.5 & 76.6 \\
\hline$K_{s}=1.2$ & 670.3 & $\mathbf{0}$ & 419.2 & 225 & 390.9 & 14.2 & 66.4 \\
\hline
\end{tabular}


Figures (5a) and (5b) present the evaluation of the eight irrigation schedules, and the soil water balance during the growth season for the four water stress coefficients ( $\mathrm{Ks}=0.6,0.8,1.0$ and 1.2) under surface drip irrigation and furrow gated pipe irrigation systems. Soil water content in the root zone can be expressed by root zone depletion, $D_{r}$, i.e., water shortage relative to field capacity. At field capacity, the root zone depletion is zero $\left(D_{r}=0\right)$.

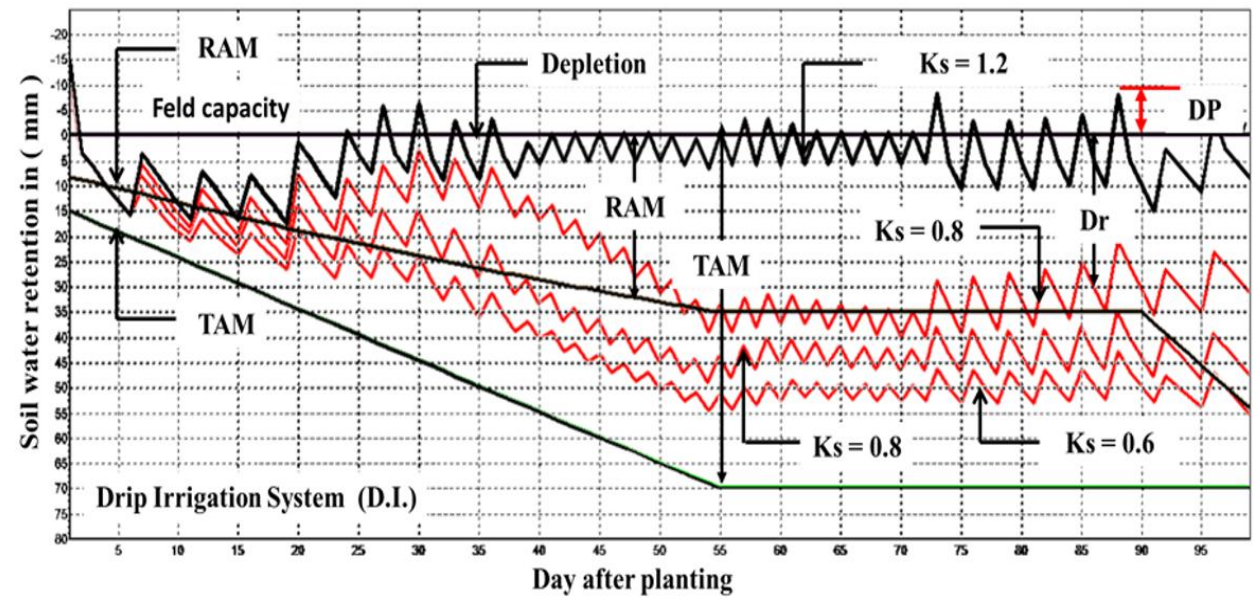

Fig. (5a): Soil water balance during the growth season for the four water stress coefficients $(\mathrm{Ks}=0.6,0.8,1$ and 1.2) under surface D.I. systems.

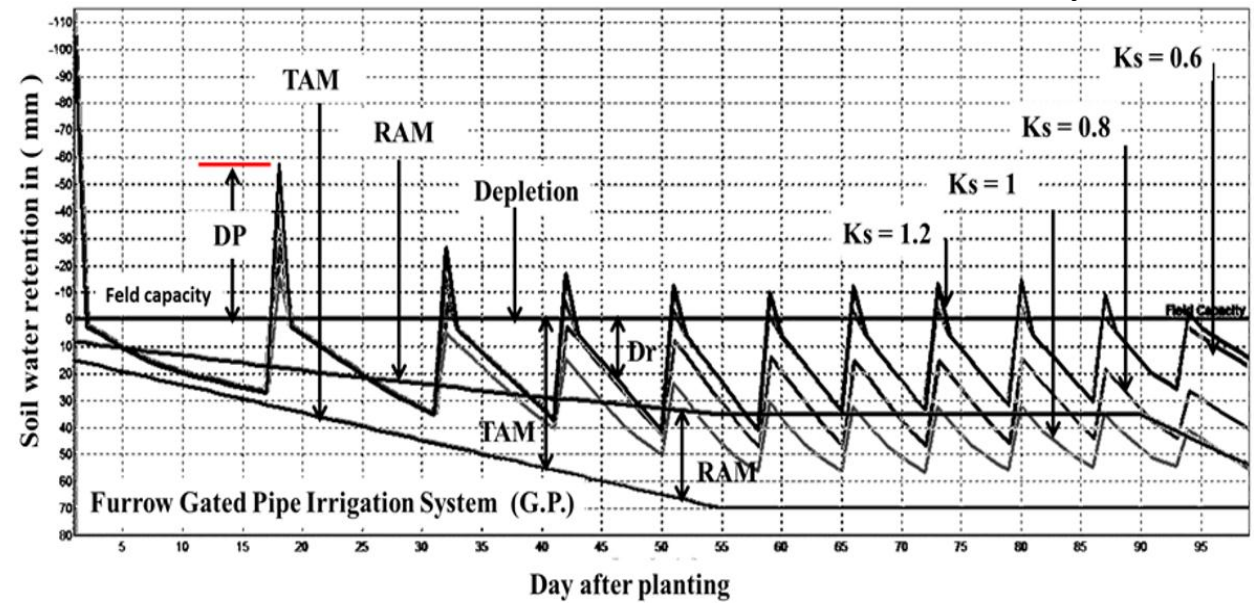

Fig. (5b): Soil water balance during the growth season for the four water stress coefficients $(\mathrm{Ks}=0.6,0.8,1$ and 1.2) under G.P. furrow irrigation system.

In case the net irrigation contribution brings the soil moisture content to exceed the field capacity (F.C), the amount of water above F.C is assumed 
to be lost to DP. If irrigation depth exceeds F.C it would be considered as irrigation losses (Swennenhuis, 2006). Fig. 5a shows that there was no significant amount of water losses by DP in drip irrigation treatments except, in case of $\mathrm{Ks}=1.2$, where the losses by DP was $52.4 \mathrm{~mm}$ which represent 0.8 of the least value of DP losses in furrow gated pipe irrigation treatment $(\mathrm{Ks}=0.6)$.

Concerning the data shown in Fig. (5b), there was countable amount of water losses by DP in all gated pipe furrow irrigation treatments $(\mathrm{Ks}=1.2$, 1.0, 0.8 and 0.6) at initial and development maize growth stages.

\subsection{Field results}

\subsubsection{Yield and irrigation water use efficiency}

The relationship between irrigation levels and the maize grain yield was closely comparable for the used irrigation systems. The maize grain yield decreased as the irrigation level decreased, except when the irrigation level increases from $\mathrm{Ks}=1.0$ to 1.2 using G.P. irrigation system, where the yield decreased by $14.11 \%$. However, the decrease in the yield differed from D.I. to G.P. irrigation system. The data illustrated in Table (6) show that the highest value of maize grain yield at $120 \%$ and $100 \%$ of $\mathrm{ET}_{\mathrm{c}}$ were 12.89 t/ha and $12.52 \mathrm{t} /$ ha respectively, with surface D.I. followed by $11.47 \mathrm{t} / \mathrm{ha}$ with furrow irrigation using G.P. at $100 \%$ of $\mathrm{ET}_{\mathrm{c}}$.

The results in Table (4) show calculation of crop water use efficiency as related to D.I. and G.P. irrigation systems and all four irrigation levels. They show that the highest values of irrigation water use efficiency (3.12, 2.83 and $2.75 \mathrm{~kg} / \mathrm{m}^{3}$ ) were obtained with D.I. at $\mathrm{Ks}=0.8,1.0$ and 1 , respectively with D.I. followed by $\left(1.98 \mathrm{~kg} / \mathrm{m}^{3}\right)$ at $\mathrm{Ks}=1$ with G.P. furrow irrigation. The lest water use efficiency value was $1.31 \mathrm{~kg} / \mathrm{m}^{3}$ registered with G.P. furrow irrigation at Ks $=0.6$.

It is also evident that, at D.I. and G.P. irrigation systems, the crop water use efficiency decreased when the application rate of water increased above $100 \%$ of $\mathrm{ET}_{\mathrm{c}}$. On the other side, at both D.I. and G.P. irrigation systems, the crop water use efficiency decreased with decreasing the application rate of water except at $80 \%$ of $\mathrm{ET}_{\mathrm{c}}$ with D.I.

Concerning the recorded crop water use efficiency, comparing between D.I. and G.P., it is clear that the D.I. system has an advantage in the water application efficient. This is due to its higher values of crop water use 
efficiency than data recorded by the G.P. furrow irrigation system. This because of the uniform distribution of moisture in the effective root zone of maize under D.I.

Table (6): Water irrigation depth, yield of maize, and water use efficiency under D.I. and G.P. irrigation systems

\begin{tabular}{|c|c|c|c|c|c|c|c|c|}
\hline \multicolumn{9}{|c|}{ Irrigation systems } \\
\hline \multirow[b]{2}{*}{ Parameters } & \multicolumn{4}{|c|}{ Drip Irrigation D.I. } & \multicolumn{4}{|c|}{ Gated Pipe Irrigation G.P. } \\
\hline & $\begin{array}{l}\text { Ks } \\
0.6\end{array}$ & $\begin{array}{l}\mathrm{Ks} \\
0.8\end{array}$ & $\begin{array}{l}\mathrm{Ks} \\
1.0\end{array}$ & $\begin{array}{l}\mathrm{Ks} \\
1.2\end{array}$ & $\begin{array}{l}\mathrm{Ks} \\
0.6\end{array}$ & $\begin{array}{l}\mathrm{Ks} \\
0.8\end{array}$ & $\begin{array}{l}\mathrm{Ks} \\
1.0\end{array}$ & $\begin{array}{l}\mathrm{Ks} \\
1.2\end{array}$ \\
\hline Irrigation amount $\left(\mathrm{m}^{3} / \mathrm{ha}\right)$ & 2774.9 & 3599.9 & 4424.9 & 6619.1 & 3951.2 & 4868.3 & 5785.4 & 6702.5 \\
\hline Yield (t/ha) & 7.63 & 11.24 & 12.52 & 12.89 & 5.17 & 7.74 & 11.47 & 10.71 \\
\hline $\begin{array}{l}\text { Irrigation water use efficiency } \\
(\text { WUE })\left(\mathbf{k g} / \mathbf{m}^{3}\right)\end{array}$ & 2.75 & 3.12 & 2.83 & 1.95 & 1.31 & 1.59 & 1.98 & 1.60 \\
\hline $\begin{array}{l}\text { Decreasing percent in yield due } \\
\text { to water application }(\%)\end{array}$ & 46.80 & 13.18 & 2.87 & 0 & 58.54 & 37.93 & 0.00 & 14.11 \\
\hline $\begin{array}{l}\text { Decreasing percent in yield due } \\
\text { to irrigation system }(\%)\end{array}$ & 0 & 0 & 0 & 0 & 32 & 31 & 0 & 17 \\
\hline
\end{tabular}

A polynomial function was fitted between seasonal irrigation applied water at different water stress coefficients and maize yield under D.I. and G.P. irrigation systems Fig. (6). According to the mathematical analysis of the grain water production function (GWPF), the predicted maximum maize grain yield (GY) was 13.42 and 10.66 t/ha under D.I. and G.P. systems, the corresponding calculated water irrigation amount was 5437.5 and 6400 $\mathrm{m}^{3} /$ ha, respectively.

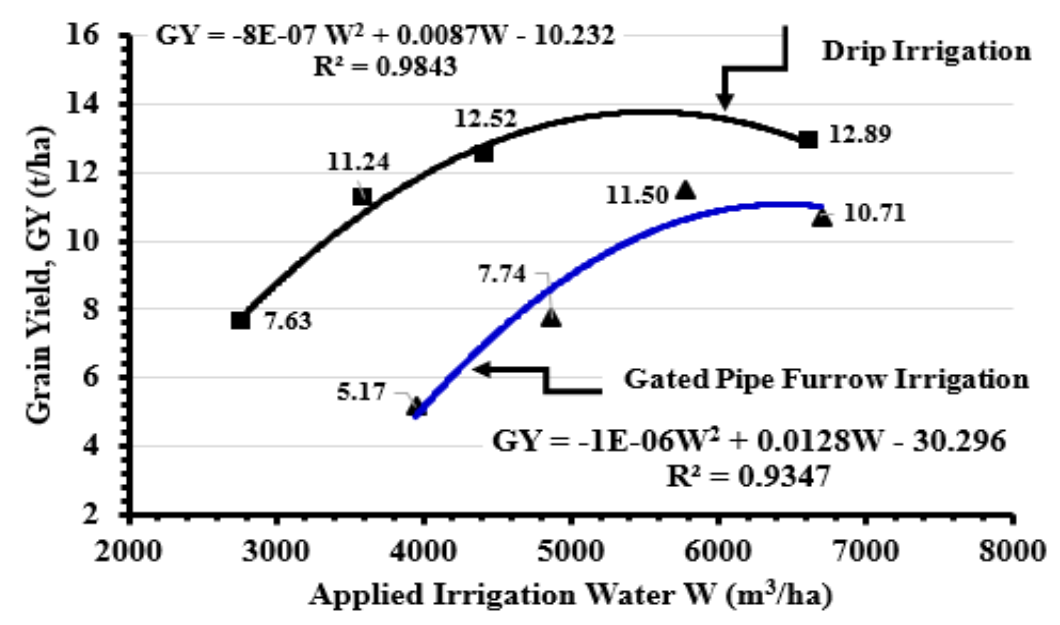

Fig. (6): Grain yield vs. applied irrigation water for Maize under drip and gated pipe irrigation systems. 
The results which could be revealed from Table (6) and Fig. (6), contradict with the results which were obtained by Shehata (2009), who stated that, the highest value of water use efficiency $\left(2.44 \mathrm{~kg} / \mathrm{m}^{3}\right)$ was obtained with furrow irrigation at $100 \%$ of $\mathrm{ET}_{\mathrm{c}}$ followed by the surface drip irrigation system $\left(1.77 \mathrm{~kg} / \mathrm{m}^{3}\right)$ at $80 \%$ of $\mathrm{ET}_{\mathrm{c}}$. Nevertheless, agreed with Abubaker et al. (2006) and Adeboye et al. (2015).

The analysis of variance for the field data from two growth seasons 2015 and 2016, showed highly significant efficiency $(p<0.01)$ for D.I. over G.P. irrigation system for all traits except plant circumference. Results in Table (7), showed highly significant increase in plants/ha and grain yield (t/ha) for D.I. system. Gated pipe furrow irrigation system showed significant increase in Ear weight (gm), grain weight (gm/1000), and plant height $(\mathrm{cm})$ over D.I. system. However, D.I. showed GWP better than G.P. $\left(2.45 \mathrm{Kg} / \mathrm{m}^{3}\right), 40 \%$ more production with lowest amount of water $(7 \%)$ at irrigation water application efficiency, 95\% and 80\% respectively. Previous researchers (Abubaker et al., 2006; Shehata, 2009), reported similar results. However, the GWP values of this study were higher than some values reported in the literature. Hassanli et al. (2009) reported that the maximum water use efficiency or GWP was obtained with the drip irrigation $\left(2.12 \mathrm{~kg} / \mathrm{m}^{3}\right)$ and the minimum was obtained with the furrow irrigation method $\left(1.43 \mathrm{~kg} / \mathrm{m}^{3}\right)$.

The analysis of variance, showed highly significant effects $(p<0.01)$ for irrigation treatments of all traits. Ks (1.0) considered the best level for number of plants per ha, ear weight (gm), grain yield (t/ha), and GWP $\left(\mathrm{Kg} / \mathrm{m}^{3}\right)$. while, Ks $(0.8)$ considered the best trial for 1000-grain weight (gm). On the other hand, the shortened plant height was found at Ks (0.6).

The data in Table (7) revealed highly significant interaction of (irrigation system * irrigation treatment) for all traits studied. The D.I. * Ks (1.0) considered the best treatment for most traits, but D.I. * Ks $(0.8)$ the best treatment for GWP $\mathrm{Kg} / \mathrm{m}^{3}$, on the other hand. D.I.* Ks (1.0) gave the highest grain yield $12.55(\mathrm{t} / \mathrm{ha})$. This result agreed with the findings of Kori et al. (2017) 
Table (7): Means of some traits as influenced by Irrigation system, and Irrigation treatment and their interactions.

\begin{tabular}{|c|c|c|c|c|c|c|c|}
\hline Factor & $\begin{array}{c}\text { No. of } \\
\text { plant/ha }\end{array}$ & $\begin{array}{c}\text { Ear } \\
\text { weight } \\
\text { (gm) }\end{array}$ & $\begin{array}{c}\text { 1000- } \\
\text { grain } \\
\text { weight } \\
\text { (gm) }\end{array}$ & $\begin{array}{c}\text { Grain } \\
\text { yield } \\
\text { t/ha }\end{array}$ & $\begin{array}{c}\text { Plant } \\
\text { circum- } \\
\text { ference } \\
(\mathbf{c m})\end{array}$ & $\begin{array}{c}\text { Plant } \\
\text { height } \\
\text { (cm) }\end{array}$ & $\begin{array}{l}\text { GWP } \\
\mathbf{K g} / \mathbf{m}^{3}\end{array}$ \\
\hline & \multicolumn{7}{|c|}{ Irrigation system } \\
\hline G.P. & $90.190 \mathrm{~b}$ & 332.30 a & 443.38 a & $9.11 \mathrm{~b}$ & 8.92 a & 291 a & $1.74 \mathrm{~b}$ \\
\hline \multirow[t]{2}{*}{ D.I } & 120.25 a & $307.39 \mathrm{~b}$ & $410.05 \mathrm{~b}$ & $11.40 \mathrm{a}$ & $8.54 \mathrm{a}$ & $274.5 \mathrm{~b}$ & $2.45 \mathrm{a}$ \\
\hline & \multicolumn{7}{|c|}{ Irrigation treatment } \\
\hline Ks (1.2) & $118.00 \mathrm{a}$ & $320.10 \mathrm{~b}$ & $427.82 \mathrm{~b}$ & $11.80 \mathrm{~b}$ & $9.26 \mathrm{a}$ & 299 a & $2.403 \mathrm{a}$ \\
\hline Ks (1.0) & $117.63 \mathrm{a}$ & $354.58 \mathrm{a}$ & 449.58 a & $12.50 \mathrm{a}$ & 8.54 bc & $283.5 \mathrm{ab}$ & $2.491 \mathrm{a}$ \\
\hline Ks (0.8) & $109.74 \mathrm{~b}$ & $317.34 \mathrm{~b}$ & 450.91 a & $9.49 \mathrm{c}$ & $8.23 \mathrm{c}$ & $283 \mathrm{~b}$ & $1.968 \mathrm{~b}$ \\
\hline \multirow[t]{2}{*}{ Ks (0.6) } & $78.880 \mathrm{c}$ & $287.36 \mathrm{c}$ & $378.55 \mathrm{c}$ & $7.25 \mathrm{~d}$ & $8.86 \mathrm{ab}$ & $266 \mathrm{c}$ & $1.506 \mathrm{c}$ \\
\hline & \multicolumn{7}{|c|}{ Irrigation system * Irrigation treatment } \\
\hline G.P. * Ks (1.2) & $104.50 \mathrm{c}$ & 334.25 b & $425.97 \mathrm{e}$ & $10.71 \mathrm{~b}$ & $9.08 \mathrm{ab}$ & 292 abc & $1.668 \mathrm{e}$ \\
\hline G.P. * Ks (1.0) & $107.00 \mathrm{c}$ & 367.82 a & $454.31 \mathrm{ab}$ & $12.47 \mathrm{a}$ & $8.32 \mathrm{ab}$ & 265 bcd & $1.942 \mathrm{~d}$ \\
\hline G.P. * Ks (0.8) & $96.500 \mathrm{~d}$ & $342.77 \mathrm{~b}$ & $461.65 \mathrm{a}$ & $7.740 \mathrm{~d}$ & $8.10 \mathrm{~b}$ & $263 \mathrm{~cd}$ & $1.210 \mathrm{f}$ \\
\hline G.P. * Ks (0.6) & $52.750 \mathrm{e}$ & $284.38 \mathrm{~d}$ & $431.62 \mathrm{de}$ & $5.530 \mathrm{e}$ & $8.64 \mathrm{ab}$ & $251 \mathrm{~d}$ & $0.860 \mathrm{~g}$ \\
\hline D.I. * Ks (1.2) & $131.50 \mathrm{a}$ & $305.95 \mathrm{c}$ & $429.67 \mathrm{e}$ & $12.88 \mathrm{a}$ & $9.42 \mathrm{a}$ & $306 \mathbf{a}$ & $2.727 \mathrm{c}$ \\
\hline D.I. * Ks (1.0) & 128.25 a & $341.35 \mathrm{~b}$ & 444.86 bc & $12.52 \mathrm{a}$ & $8.73 \mathrm{ab}$ & 302 ab & $3.040 \mathrm{~b}$ \\
\hline D.I. * Ks (0.8) & $122.25 \mathrm{~b}$ & $291.92 \mathrm{~d}$ & $440.17 \mathrm{~cd}$ & $11.24 \mathrm{~b}$ & $8.32 \mathrm{ab}$ & 303 a & $3.138 \mathrm{a}$ \\
\hline D.I. * Ks (0.6) & $99.000 \mathrm{~d}$ & $290.34 \mathrm{~d}$ & $325.49 \mathrm{f}$ & $8.970 \mathrm{c}$ & $9.08 \mathrm{ab}$ & 281 abcd & $2.153 \mathrm{~d}$ \\
\hline C.V & 2.42 & 1.97 & 1.50 & 3.5 & 9.8 & 8.9 & 7.8 \\
\hline
\end{tabular}

Means followed by the same letter(s) are not significant, but different letters are significant at 0.05 level.

\section{CONCLUSIONS}

The objective of this study was to evaluate the effects of deficit irrigation regimes $(60 \%, 80 \% 100 \%$ and $120 \%$ of ETc) under surface drip irrigation (I.D.) and furrow irrigation using gated pipe (G.P.) on maize (Zea mays L., Varity Single Cross No. 10) on grain yield in heavy soil and irrigation water use efficiency under Egyptian climatic condition. The field results showed significant differences between irrigation methods and its levels on grain water production (average of two seasons) 7.63, 11.24,12.52 and 12.89 t/ha at irrigation amount of $2774.9,3560,4425$ and $6619.1 \mathrm{~m}^{3} /$ ha respectively, under D.I and 5.17, 7.74, 11.47 and $10.71 \mathrm{t} / \mathrm{ha}$ at amount of water 3951.2, 4868.3, 5785.4 and $6702.5 \mathrm{~m}^{3} /$ ha respectively for G.P. furrow irrigation. However, D.I. showed grain water production (GWP) better than G.P. by $40 \%$ more production with lowest amount of water by $7 \%$. The analysis of variance revealed highly significant interaction of (irrigation system * 
irrigation treatment) for all traits studied. The drip irrigation (D.I.) $* \mathrm{Ks}$ (1.0) considered the best treatment for most traits, but D.I. * Ks $(0.8)$ is considered the best treatment for GWP in $\mathrm{Kg} / \mathrm{m}^{3}$. In average, drip irrigation consumed $74.7 \%$ of water compared to the furrow gated pipe irrigation system at the same water stress. Thus, achieving higher water use efficiencies. This study showed that, there is a great reference for water saving when using drip or drip-deficit irrigation compared with surface irrigation.

\section{ACKNOWLEDGMENT}

My sincere thanks and appreciation to Prof. Dr. Samir Ismail (Prof. of irrigation system, Agricultural and Biosystems Engineering Department, Faculty of Agriculture، Alexandria University, Egypt) for his support and valuable advices during all stages of this study.

\section{REFERENCES}

Abou Kheira A. (2005) A study of trickle irrigation systems for irrigating some horticultural crops in Delta soils, Ph. D. thesis. Shebin El-Kom, Minufiya University, Egypt.

Abubaker S., Shawa F., Smaita A. and Mansor T. (2006) Comparison of modern irrigation methods (Drip, Sprinkler) with surface irrigation method (furrow) for maize production. Damascus University Journal for the Agricultural Sciences 22:427-450.

Adeboye O.B., Schultz B., Adekalu K.O. and Prasad K. (2015) Crop water productivity and economic evaluation of drip-irrigated soybeans (Glyxine max L. Merr.). Agriculture \& Food Security 4:10.

Allen R.G., Pereira L.S., Raes D. and Smith M. (1998) Crop evapotranspiration-Guidelines for computing crop water requirements-FAO Irrigation and drainage paper 56. Fao, Rome 300:D05109.

Aly A. and Benaabidate L. (2010) Salinity of water resources in the Siwa Oasis: monitoring and diagnosis. Water-rock interaction. London: Taylor \& Francis. ISBN:978-970.

Bouwer H. (1986) Intake rate: cylinder infiltrometer, in: A. Klute (Ed.), Methods of Soil Analysis: Part 1-Physical and Mineralogical 
Methods, Soil Science Society of America, Madison, Wisconsin. pp. 825-844.

Cuenca R.H. (1989) Irrigation system design. An engineering approach Prentice Hall, Englewood Cliffs, NJ.

Doorenbos J. (1975) Guidelines for predicting crop water requirements.

Food and Agriculture organization. Rome, Irrig. Drainage pap. 24.

Doorenbos J. and Kassam A. (1979) Yield response to water. Irrigation and drainage paper 33:257.

Doorenbos J. and Pruitt W. (1977) Crop water requirements. Irrigation and drainage paper no. 24. Fao, Rome.

El-Shafei A., Allam K. and Hamad T. (2015) Simulation and Field Verification of Water Management Strategies and Wheat Crop Production, The 20th Annual Conference of Misr Society of Agricultural Engineering, Agricultural Engineering and Country Challenges, Faculty of Agricultural, Banha University, Egypt. pp. 427-458.

English M. (1990) Deficit Irrigation. I: Analytical Framework. Journal of Irrigation and Drainage Engineering 116:399-412.

FAO. (2005) Fertilizer use by crop in Egypt Food And Agriculture Organization Of The United Nations, Rome. pp. 57.

Hassanli A.M., Ebrahimizadeh M.A. and Beecham S. (2009) The effects of irrigation methods with effluent and irrigation scheduling on water use efficiency and corn yields in an arid region. Agricultural Water Management 96:93-99.

Helweg O.J. (1991) Functions of crop yield from applied water. Agronomy Journal 83:769-773.

Hillel D. (1971) Soil and water: Physical principles and processes Academic Press, New York.

Ismail S. (1993a) Optimal irrigation and wheat yield response to applied water. Journal of King Saud University 5:41-56. 
Ismail S. (1993b) Sprinkler-irrigated wheat production function and mathematical optimization. Alexandria Journal of Agricultural Research (Egypt).

Israelson O.W. and Hanson V.E. (1962) Irrigation Principal and Practices, John Wiley and Sons Inc., New York.

Jackson M. (1962) Soil chemical analysis.,(Prentice Hall, Inc., Englewood cliffs, NJ, USA.

Kijne J.W., Barker R. and Molden D.J. (2003) Water productivity in agriculture: limits and opportunities for improvement Cabi

In Assosiation with the International Water Management Institute, Wallingford, UK.

Kirda C., Cetin M., Dasgan Y., Topcu S., Kaman H., Ekici B., Derici M.R. and Ozguven A.I. (2004) Yield response of greenhouse grown tomato to partial root drying and conventional deficit irrigation. Agricultural Water Management 69:191-201.

Kori S., Soothar C., Qureshi A. and Ashrafani S. (2017) Effect of Different Irrigation Methods on Water use Efficiency and Yield of Maize Crop. Pakistan Journal of Agriculture, Agricultural Engineering. and Vet. Sci. 33:54-65.

Marica A. (2005) Study of the CROPWAT model in Romania. Irrigation and Pest and Disease Models: Evaluation in Different Environments and Web-Based Applications, European Commission, Directorate General XII, Science, Research and Development, Environment Research Programme-COST Action 718:62-72.

Melvin S. and Payero J. (2007) Irrigation water conserving strategies for corn, The 19th Annual Central Plains Irrigation Conference \& Exposition, Citeseer, Kearney, Nebraska. pp. 53-61.

NeSmith D.S. and Ritchie J.T. (1992) Short- and Long-Term Responses of Corn to a Pre-Anthesis Soil Water Deficit. Agronomy Journal 84:107-113. 
Omara A.I. (1997) Implementation and evaluation of gated pipe for furrow irrigation system, Agricultural Engineering Alexandria University, Egypt.

Oweis T.Y. and Hachum A.Y. (2003) 11 Improving Water Productivity in the Dry Areas of West Asia and North Africa. Water productivity in agriculture: limits and opportunities for improvement 1:179.

Payero J.O., Klocke N.L., Schneekloth J.P. and Davison D.R. (2006a) Comparison of irrigation strategies for surface-irrigated corn in West Central Nebraska. Irrigation Science 24:257-265.

Payero J.O., Melvin S.R., Irmak S. and Tarkalson D. (2006b) Yield response of corn to deficit irrigation in a semiarid climate. Agricultural Water Management 84:101-112.

Payero J.O., Tarkalson D.D., Irmak S., Davison D. and Petersen J.L. (2008) Effect of irrigation amounts applied with subsurface drip irrigation on corn evapotranspiration, yield, water use efficiency, and dry matter production in a semiarid climate. Agricultural Water Management 95:895-908.

Richards L. (1949) Methods of measuring soil moisture tension. Soil Science 68:95.

SAS Institute Inc. (2008) Changes and Enhancements User's Guide, SAS Technical Report AS/STAT Software, Version 9.1.3, Cary, NC, USA.

Savva A.P. and Frenken K. (2002) Irrigation manual: planning, development monitoring and evaluation of irrigated agriculture with farmer participation.

Shehata A.A.-A. (2009) Comparison among different irrigation systems for deficit-irrigated corn in the Nile Valley. Agricultural Engineering International: CIGR Journal.

Steel R.G.D., Torrie J.H. and Dickey D.A. (1980) Principles and procedures of statistics: A biometrical approach. 2nd ed. McGrawHill, New York, USA. 
Stewart J., Cuenca R., Pruitt W., Hagan R. and Tosso J. (1977) Determination and utilization of water production functions for principal California crops, W-67 California Contributing Project Report, University of California

Davis, United States of America. Swennenhuis J. (2006) CROPWAT Version 8.0. Water Resources Development and Management Service, FAO, Rome.

Traore S.B., Carlson R.E., Pilcher C.D. and Rice M.E. (2000) Bt and nonBt maize growth and development as affected by temperature and drought stress. Agronomy Journal 92:1027-1035.

Trooien T.P., Buschman L.L., Sloderbeck P., Dhuyvetter K.C. and Spurgeon W.E. (1999) Water Use Efficiency of Different Maturity Corn Hybrids and Grain Sorghum in the Central Great Plains. Journal of Production Agriculture 12:377-382.

Zegbe-Domínguez J.A., Behboudian M.H., Lang A. and Clothier B.E. (2003) Deficit irrigation and partial rootzone drying maintain fruit dry mass and enhance fruit quality in 'Petopride' processing tomato (Lycopersicon esculentum, Mill.). Scientia Horticulturae 98:505510.

Zohry A., Ouda S. and Noreldin T. (2016) Solution for Maize production consumption Gap in Egypt, 4th African Regional Conferences on Irrigation and Drainage (ARCID), Aswan, Egypt. pp. 1-12.

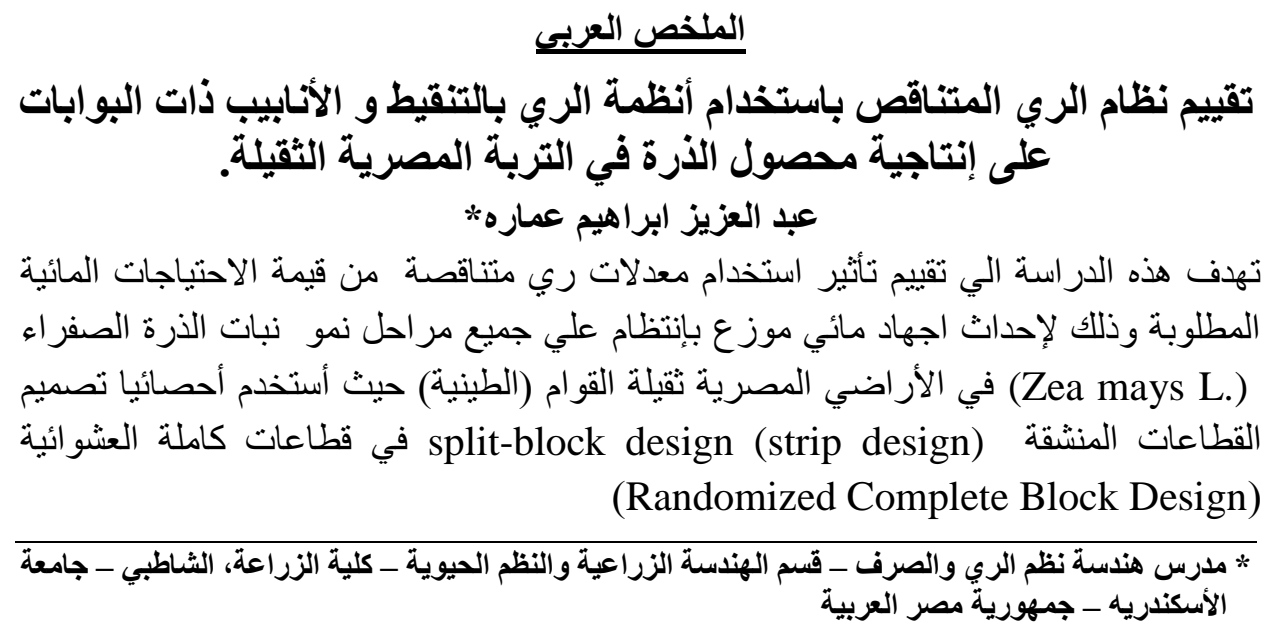




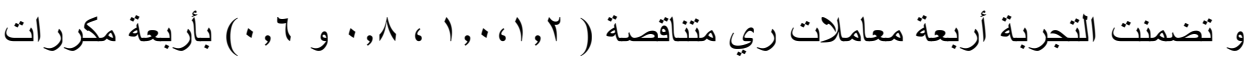

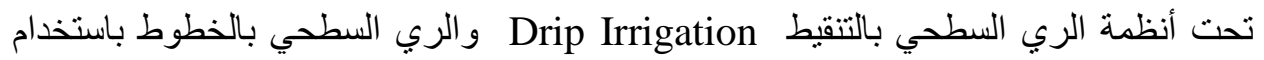

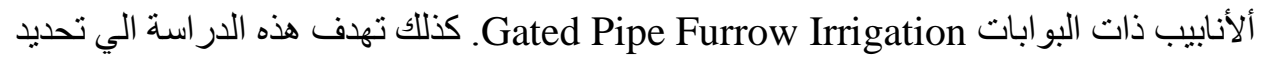

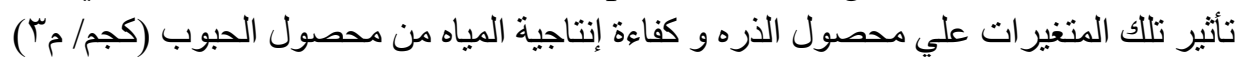

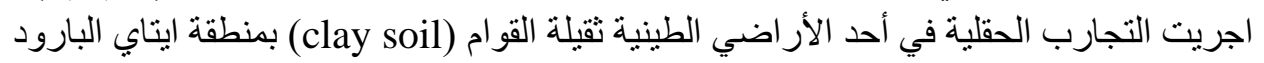

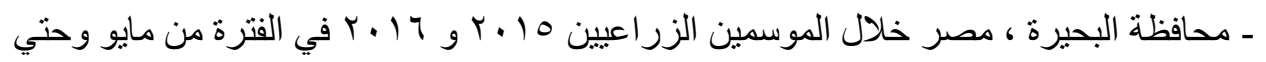

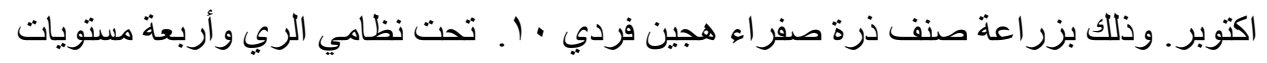

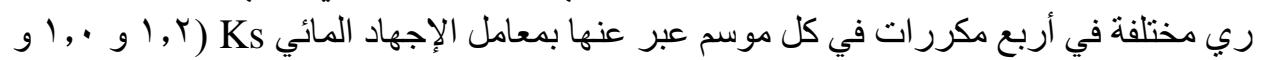

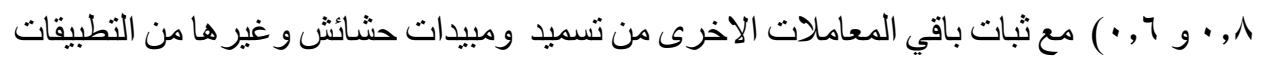

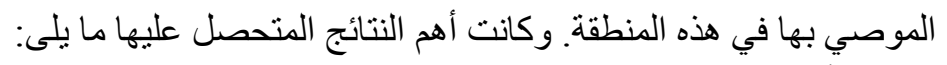

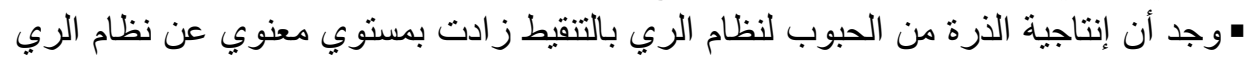

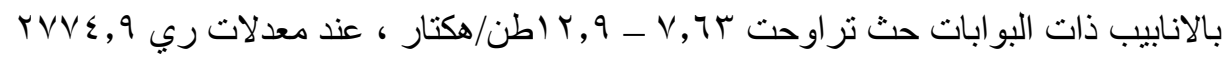

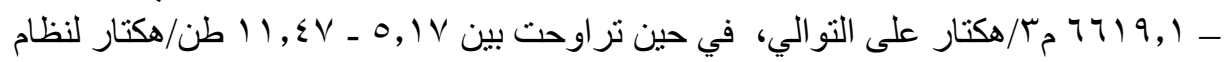

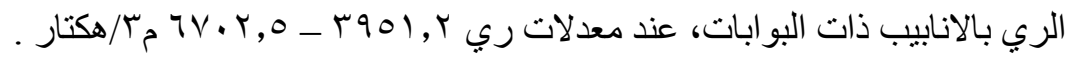

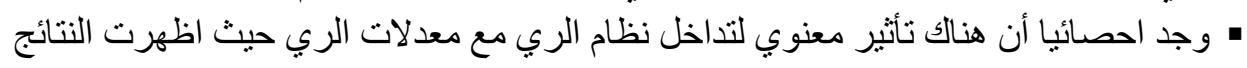

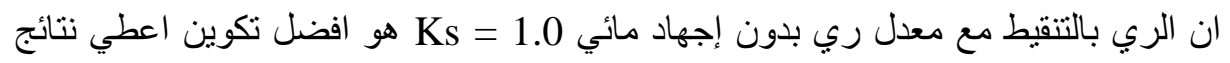

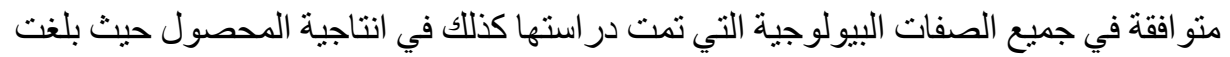

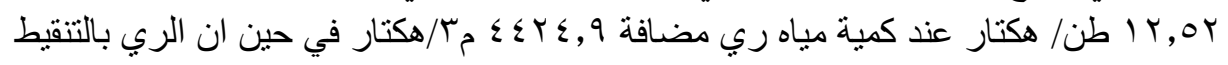
مع معدل إجهاد مائي

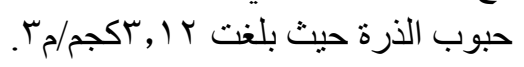

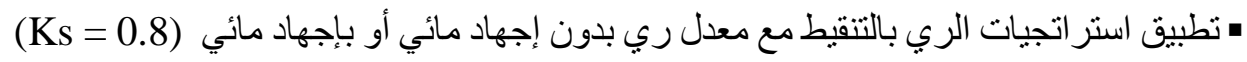

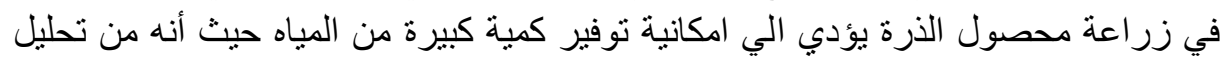

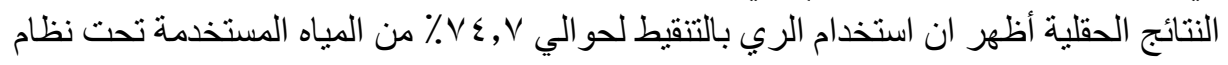

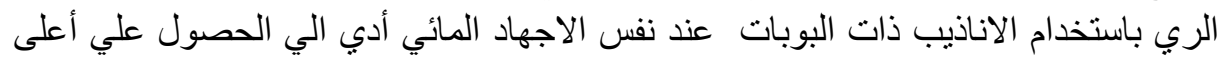

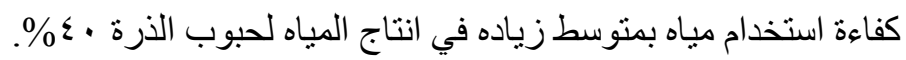

